\title{
YUGOSLAV DIPLOMATS DURING THE INTERWAR PERIOD ${ }^{1}$
}

\author{
SRĐAN MićIĆ
}

\begin{abstract}
Yugoslav diplomats during the interwar period.
The article deals with influence of the Serbian elite in the scope of the Yugoslav Foreign Service during 19181939. The influence of the elite circles was particularly prominent in the Yugoslav Army and in the Ministry of Foreign Affairs, as was the case in Serbia until 1918. As non-institutional factors had great influence on the work of state institutions, the first aim of this paper is to examine the main aspect for selection, career development and obstacles in the life of Yugoslav Diplomats, derived from the power struggle among elite circles. The second aim is to compare Serbian and Yugoslav experiences in order to establish similarities and differences in the characteristics of the pre-War and Interwar Diplomatic-Consular personnel. The analysis is based on Yugoslav archival materials, as well as on foreign published documents, memorial literature and relevant Yugoslav/Serbian and foreign historiography.
\end{abstract}

Author: Srđan Mićić, Institute for Modern History of Serbia, Trg Nikole Pašića 11/IV, 11000 Belgrade, Serbia, srdjan.micic@inis.bg.ac.rs

Keywords: Serbian elite, Yugoslav foreign service, Yugoslav military service

Balcanica Posnaniensia. Acta et studia, XXV, Poznań 2018, Wydawnictwo Instytutu Historii UAM, pp. 143159, ISBN 978-83-65663-94-8, ISSN 0239-4278. English text with summary in English.

doi.org/10.14746/bp.2018.25.9

The Kingdom of Serbia represented the most important factor of Yugoslav unification, but not the only one. Serbian elite accepted the idea of sacrificing existing statehood and tradition, and ending constitutional order, during the First World War, in order to clear the path for the creation of the Kingdom of Serbs, Croats and Slovenes and the adoption of a new constitution. However, it did not mean that elite circles were anxious to give up the leading role in the new South Slavic state. ${ }^{2}$ They managed to

${ }^{1}$ This article is the result of work on the research project of the Institute for the Modern History of Serbia Serbs in Yugoslav and International Context: Internal Development and Position in European/ World Community (No 47027), financed by the Ministry of Education, Science and Technological Development of the Republic of Serbia.

${ }^{2}$ For further reading: Љ. Димић, Историја српске државности, vol. 3 (Србија у Југославији), Нови Сад 2001; Branko Petranović, Istorija Jugoslavije 1918-1988, Knjiga I, Kraljevina Jugoslavija 1914-1941, Beograd 1989. 
preserve distinguished positions in Yugoslav State Institutions during the Interwar Period. Their dominance was particularly prominent in the Army and the Ministry of Foreign Affairs, including the diplomatic-consular service. ${ }^{3}$

The role of officer corps in the Balkan states at the end of the 19th and the beginning of the 20th century was not only of the military service. They represented technical intelligentsia which significantly contributed to society modernisation and national emancipation. The officers were preoccupied with domestic and foreign policies, though military interference was legally prohibited. ${ }^{4}$ The involvement of the officers and (para)military elements was manifesting more evidently after the First World War not only at the Balkans yet as well on the territories of former great empires in the Central and Eastern Europe. They were seen as an element of stability in the confusions provoked by different internal and foreign dangers. ${ }^{5}$ In the case of the Yugoslav military service, Serbs have generated great self-confidence through victorious wars in 1912-1918 against mightier enemies (Ottomans in 1912, Austro-Hungarians in 1914 and Germans in 1918), and they had reasonable doubts in loyalty and some prejudices concerning the competences of the former $\mathrm{k}$. und $\mathrm{k}$. officers in the Yugoslav army. Therefore the officer corps largely consisted of Serbs, who held all the major posts in the Army. Former Austro-Hungarian officers had a distinguished role only in the Navy, since there was now prewar Serbian naval corps which could guarantee normal functioning of that important branch of the armed forces against Italian aggression plans. ${ }^{6}$

Although similar patterns existed in military and civil circles among the Serbian elite, the redistribution of the positions in the civil service was somewhat different. Due to Serbo-Croatian relations which were the main obstacle for the establishment of internal unity and preservation of the stability of the state, Slovenes and Muslims had more opportunities for employment in state and municipal institutions due to the political cooperation with Serbs. ${ }^{7}$ Nevertheless, the Serbian elite was holding firmly in their hands the positions in the Ministry of Foreign Affairs and diplomatic-consular

${ }^{3}$ For further reading: Срђан Мићић, Од бирократије до дипломатије. Историја југословенске дипломатске службе 1918-1939, Београд 2018, p. 183, 184; M. S. Bjelajac, Generali i admirali Kraljevine Jugoslavije 1918-1941. Studija o vojnoj eliti i biografski leksikon, Beograd 2004, p. 13, 1821; Mile Bjelajac, Vojska Kraljevine SHS/Jugoslavije 1922-1935, Beograd 1994, 56, 57; Mile Bjelajac, Vojska Kraljevine Srba, Hrvata i Slovenaca 1918-1921, Beograd 1988, p. 55.

${ }^{4}$ Dimitrije Djordjević, The Role of the military in the Balkans in the nineteenth century, in: Der Berliner Kongress von 1878: Die Politik der Grossmächte und die Probleme der Modernisierung in Südosteuropa in der zweiten Hälfte des 19. Jahrhunderts, eds. Ralph Melville, Hans-Jürgen Schröder, Wiesbaden 1982, s. 317-347; Mile Bjelajac, Vojska kao faktor modernizacije, in: Srbija u modernizacijskim procesima XX veka: naučni skup, ed. L. Perović, M. Obradović, D. Stojanović), Beograd 1994, p. 355-361.

5 John Paul Newman, Yugoslavia in the shadow of war: veterans and the limits of state building, 1903-1945, Cambridge 2015, p. 51.

${ }^{6}$ M. S. Bjelajac, Generali i admirali Kraljevine Jugoslavije 1918-1941, p. 18-21; М. Бјелајац, Југословенско искуство са мултиетничком армијом 1918-1991, Београд 1999, p. 11-46; M. Bjelajac, Vojska Kraljevine Srba, Hrvata i Slovenaca 1918-1921, p. 93-103.

${ }^{7}$ B. Petranović, Istorija Jugoslavije 1918-1988, I, p. 142, 144, 146-149, 167,168. 
service. As in the case of the military service, it was considered that successes during the wars in 1912-1918 were justifying continuity in handling the Foreign Policy as well as the diplomatic service. On the other hand, there were some reasonable doubts concerning the loyalty of former Austro-Hungarian civil clerks and consular staff, who wanted to continue their career or enter the service in the newly formed Yugoslav Ministry of Foreign Affairs. ${ }^{8}$

After the First World War there were major shifts of power in the highest rank of Yugoslav society. When Karađorđević dynasty retrieve Serbian throne in 1903, King Petar I had to accept a new constitution which reestablished parliamentarianism in his absence and was imposed on the newly elected Monarch after his arrival in Serbia. Since the bloody dethronement of Obrenović dynasty was an act of conspiring officers and prominent politicians, the power was divided between the Peoples Radical Party, as the strongest political organization, and the officers gathered in the conspiratorial organization Unification or death (also known as the Black Hand). During the First World War Regent Aleksandar with the support of radicals unshackled themselves from the officers' organization during Salonica Trial in 1917. At the beginning of Yugoslav statehood, political authority was divided among three pivots: Regent and later King Alexander, the strongest parties in the Serbian part of political specter, and the officer clique loyal to the dynasty led by colonel (later general) Petar Živković (known as the White hand). Political life during the 1920s was characterized by their mutual competition and power-struggle. Aleksandar Karađorđević, unlike his father, demonstrated his appetite for control over political life from the beginning of the Yugoslav statehood and used different means for reaching this goal. Two strongest parties in the Serbian part of political specter were the Peoples Radical Party (PRP) and the Yugoslav Democratic Party (YDP). They were competing on three levels. The first was securing support from the Court, the second was gaining grounds among the voters and the third one was establishing close ties with military circles. Members of the so-called White Hand were gradually overtaking the highest ranks in the Army. The first step was removing the high-ranking officers who had proven their competence during the wars in 1912-1918, which allowed the members of the officer clique faster carrier advancement. They were gradually taking major posts in the Army as it was conspicuous after Petar Živković became the Prime Minister. In the same time they were establishing close relations with prominent politicians and businessmen. As the King Aleksandar was gradually becoming the main power pivot in the state, his influence was steadily increasing and he was taking control over foreign and later internal policy. No wonder then that his sway over the state institutions was growing bigger by the time. Culmination was his decision to establish dictatorship as an answer to critical political situation in late 1928 and beginning of $1929 .{ }^{9}$

\footnotetext{
${ }^{8}$ С. Мићић, Од бирократије до дипломатије, р. 169-183.

${ }^{9}$ For further reading: Мира Радојевић, Милан Грол, Београд 2014; Vasa Kazimirović, Crna ruka: ličnosti i događaji u Srbiji od Majskog prevrata 1903. do Solunskog procesa 1917. godine, Novi Sad
} 
The Yugoslav Ministry of Foreign Affairs, diplomatic and consular services were formed almost entirely on the basis of existing Serbian institutions as the new state emerged after the First World War. ${ }^{10}$ Consequently, the staff was simply shifted from older Serbian to newer Yugoslav institution so the prewar clerks and officials maintained their statuses. ${ }^{11}$ The employment of new staff was not in accordance with ratios among the Yugoslav population. Clerks from Vardar Macedonia and Montenegro were able to get employment in the service as soon as the First World War ended. The selection of Macedonians was based on their Serbian origin. Some of them entered Serbian diplomatic service during the war of1912-1918, while others were employed in Yugoslav Ministry for their proven adherence to the idea of the South Slav liberation and unification. ${ }^{12}$ As far as Montenegrins were concerned they could enter the service as self-declared Serbs or pronounced propagators of the Yugoslav idea. In that sense, special recommendations were (para)military service during 1912-1918 or en-

2013; Dušan Bataković, Storm over Serbia: the Rivalry between civilian and military authorities (19111914), “Balcanica”, 2013, vol. 44; Бранислав Глигоријевић, Историја Демократске странке 1919 1928, Београд 2010; Драгољуб Р. Живојиновић, Краљь Петар I Карађорђевић у отаибини 19031914. године, Београд 2009; Dušan Bataković, Nikola Pašic, les radicaux de et la "Main noire”: Les défis à la démocratie parlementaire serbe (1903-1917), "Balcanica”, 2006, vol. 37; M. S. Bjelajac, Generali i admirali Kraljevine Jugoslavije 1918-1941; Бранислав Глигоријевић, Краљ Александар Карађорђевић: српско-хрватски спор, Београд 2002; Љ. Димић, Историја српске државности, Knjiga III; M. Bjelajac, Vojska Kraljevine SHS/Jugoslavije 1922-1935; David MacKenzie, Apis, the Congenial Conspirator: the Life of Colonel Dragutin T. Dimitrijević, New York 1989; B. Petranović, Istorija Jugoslavije 1918-1988, Knjiga I; M. Bjelajac, Vojska Kraljevine Srba, Hrvata i Slovenaca, 1918-1921; Dušan Bataković, Sukob vojnih i civilnih vlasti u Srbiji u proleće 1914., "Istorijski časopis”, 1982-1983, vol. 29-30; Branislav Gligorijević, Parlament i političke stranke u Jugoslaviji (1919-1929), Beograd 1979; Надежда Јовановић, Политички сукоби у Југославији 1925-1928., Београд 1974; Milan Živanović, Pukovnik Apis: solunski process hiljadudevetstosedamnaeste: prilog za proučavanje političke istorije Srbije od 1903. do 1918. godine, Beograd 1955.

10 There were a few examples of using existing Montenegrin network as were the cases with Skadar (Shkodër) or Montreal. The Kingdom of SCS used Montenegrian facilities before the formal opening of the Consulate in Skadar (AY, 334-Personal Section-82-241, folio 204; AY, 334-Personal Section-143466, folios 415-420; AY, 334-Persona Section-178-501, folios 14, 15; AY, 334-Personal Section-205528, folios 491, 492). The Ministry of Foreign Affairs confirmed former Montenegrin honored consul in Montreal Anto Seferović as Yugoslav consul; Šerbo Rastoder, Crnogorska emigracija u vrijeme nestanka Crne Gore i nastanka Sovjetske Rusije, "Matica", 2016, no 65, p. 268, 269; Srđan Mićić, Mission of Konstantin Todorov in North America 1927-1928: Yugoslav Foreign Service vs. Macedonian-Bulgarian organizations in North America, “Токови историје, 2015, по 1, р. 91; Милић Ф. Петровић, Пљеваљичи у служби дипломатије Краљевине Југославије (1919-1945), “Гласник Завичајног музеја”, 2013 , vol. 8-9, p. 269; Dr Ubavka Ostojić-Fejić, Sejdinjene Američke Države i Srbija 1914-1918, Beograd 1994, p. $195,197$.

11 С. Мићић, Од бирократије до дипломатије, р. 73, 231; М. Ф. Петровић, Пљеваљии у служби дипломатије Краљевине Југославије (1919-1945), р. 251, 252.

12 AY, 334-Personal Section-147-470, folios 943 (pages 1-4), 944-947; AY, 334-Personal Section149-472, folios 843, 844, 874, 875, 893, 894, 896-899; AY, 334-Personal Section-152-457, folios 230233; AY, 334-Personal Section-159-482, folios 706 (pages 1-11), 707-710; AY, 334-Personal Section-184507, folios 470, 473, 474, 478, 483, 484; AY, 334-Personal Section-197-520, folio 337 (pages 1-6). 
deavors for liberation and unification of South Slavs. ${ }^{13}$ Yet, it did not mean that those loyal to the former Montenegrin dynasty Petrović ${ }^{14}$ or even republicans ${ }^{15}$ were unable to become clerks in the Ministry of Foreign Affairs. As far as republicans were concerned admission was not denied either to Serbs or to Montenegrins. For instance Milovan Prodanović and Stanoje Simić, son and son-in-law respectively of the leader of the Yugoslav Republican Party Jaša Prodanović, were clerks in the Ministry of Foreign Affairs. ${ }^{16}$ Employing close relatives of the opposition politicians was useful to tranquil criticism of the Government's Foreign Policy. Exemplary was the case of Milan M. Jovanović, brother of Jovan M. Jovanović (known under nickname Pižon) who was publicly and privately disapproving government policy toward Albania. ${ }^{17}$ In order to calm his criticism, the PM Nikola Pašić and Minister of Foreign Affairs Momčilo Ninčić, both radicals, appointed Milan Jovanović as head of the IV Section of the Political Department of the Ministry of Foreign Affairs which was in charge of work toward Albania. ${ }^{18}$ Slovenians were primarily entering the service on the ground of cooperation between Serbian and Slovenian politicians in Yugoslav governments. Some of them were employed on other grounds. For instance, Ivan Hribar and Bogumil Vošnjak were appointed as first two Yugoslav plenipotentiary ministers in Prague as they have had established close relations with some of the prominent

${ }^{13}$ AY, 334-PersonalSection-143-466, folios 399 (pages 1-4), 400-403; AY, 334-PersonalSection164-487, folio 799 (pages 1-4); AY, 334-PersonalSection-176-499, folios 685 (pages 1-4), 686 (pages 1-6); AY, 334-PersonalSection-179-502, folio 1 (pages 1-4); AY, 334-PersonalSection-188-511, folio 25 (pages 1-6); М. Ф. Петровић, Пљеваљии у служби дипломатије Краљевине Југославије (1919-1945), p. 261-263, 267, 269.

${ }^{14}$ Archive of Yugoslavia, Personal records of Milan Stojadinović (37), box 31, folder 230, folios 226, 232; Archive of Yugoslavia, Records of the Central Press bureau (38), box 35, folder 82 Arsen Gazivoda to Bata[Milan Jovanović-Stoimirović], London, $10^{\text {th }}$ October 1935; AY, 334-Personal Section-145-468, folios 477 (pages 1-4), 482, 486, 490; AY, 334-Personal Section-150-473, folios 194, 195, 197; AY, 334-Personal Section-183-506, folios 859, 860, 863, 864, 891, 900-902, 905, 907; AY, 334-Personal Section-187510, folios 384 (pages 1-4), 385-387, 405, 408-410, 445; Archive of Yugoslavia, Records of the Ministry of Foreign Affairs of the Kingdom of Yugoslavia (334), Consular-economy Department, box 225, folder 580 Consular-trade Department of the Ministry of Foreign Affairs to the Legation in Berlin, C.T.No.3879 from 12 $2^{\text {th }}$ July; Slava Ramadanović to the Consular-trade Department, No.52 from $27^{\text {th }}$ October 1922 (further: AY, 334-Consular-economy Department).

${ }^{15}$ Archive of the Serbian Academy of Sciences and Arts, (14.329) Никола Станаревић, Југословенска републиканска странка I (оснивање странке и њен рад до 1941), p. 173-175.

${ }^{16}$ AY, 334-Personal Section-185-508, folios 371, 372; AY, 334-Personal Section-191-514, folios 1 (pages 1-4), 4-7.

${ }^{17}$ Archive of Serbia, Collection of documents of Security Informational Agency, list no. III, item no 114, Elaborate [written by Dragoljub (Dragi) Jovanović] Albania during the Interwar period (based on memoirs, confidential archives and personal work in the field and in the Albanian or Balkan section of the Ministry of Foreign Affairs), Belgrade, May 11 th, 1952, p. 15, 27 [further referring as: AS, SIA]; Саша Мишић, Албанија: пријатељь и противник. Југословенска политика према Албанији 1924-1927, Београд 2009, p. 210-214; Мр Љубомир Петровић, Југословенска држава и друштво у периодиии 1920-1941, Београд 2000, p. 181, 182.

18 AS, SIA, list no III, item no. 114, Elaborate, pp. 45, 47; AY, 334-Personal Section-59-163, folios 85, 86; AY, 334-Personal Section-158-481, folios 924-926, 928-930, 936. 
Czech politicians prior to $1918 .{ }^{19}$ Leonid Pitamic was used as an expert for international law in several different capacities. Lastly he was for five years Yugoslav plenipotentiary minister in Washington. ${ }^{20}$ The number of Slovenian clerks grew steadily in the second half of 1930s and only few were appointed or considered for highest posts. ${ }^{21}$ Even though party leaders of the Yugoslav Muslim Organization were ministers in governments, The Muslim personnel in the Ministry of Foreign Affairs was far less visible then their Slovenian counterpart. Prominent Muslims were used as loyal Yugoslav subjects, for instance, in different fields of work toward Turkey, which was an important state for the Balkan Policy of the Kingdom of SCS. ${ }^{22}$ Unlike all those groups there was significant inconsistence in the employment of Croats during the Interwar Period, not only in their numbers but also in assigning positions in Ministry

${ }^{19}$ Ivan Hribar was one of the first prominent Slovenian politicians who established personal connections with Nikola Pašić before the First World War. He was the one who proclaimed the dissolution of Slovenia from the Habsburg Monarchy and its entrance into the Yugoslav state. He developed a close collaboration with Karel Kramár , who was one of the most influential Czech politicians in the first two decades of the XX Century, since both of them had similar ideals based on the Slav unity and cooperation. Therefore, he was the first Yugoslav plenipotentiary minister in Prague, 1919-1921 (AY, 334-Political Department-7-25, folio 569; AY, 334-Personal Section-93-296, folio 114; Marteja Keršić-Svetel, Československi stiki med svetovnima vojnama (1. del), "Zgodovinski časopis", 1995, vol. 49, no 2 (1995), p. 236; Božo Repe, Zakaj so Slovenci vstopili v Jugoslavijo in zakaj so iz nje odšli?, in: Jugoslavija v času-devetdeset let od nastanka prvo jugoslovenakse države, ed. Bojan Balkovec, Ljubljana 2009, p. 27, 31; Ladislav Hladký, David Blažek, Česko-slovinské vztahy, in: Vztahy Čechů s národy a zeměmi jihovýchodni Evropy, ed. Ladislav Hladký and others, Praha 2010, p. 31, 32; Andrej Rahten, Očrt slovenske diplomacije ali diplomacije Slovencev, "Teorija in praksa", 2011, vol. 43, no 3, p. 657. Ivan Hribar resigned from his diplomatic post as he was appointed the deputy head for Slovenia. After taking the new post he was one of the founders of the Yugoslav-Czechoslovakian League in Ljubljana (AY, 334-Personal Section-201-524, folio 3; Marteja Keršić-Svetel, Česko-slovenski stiki med svetovnima vojnama (3. del), "Zgodovinski časopis", 1995, vol. 49, no 4, p. 616. Bogumil Vošnjak was also a prominent Slovenian politician who created, as a member of the Yugoslav Committee, close relations with Tomáš Masaryk and Edvard Beneš during the First World War (AY, 334-Personal Section-93-296, folios 122-125; B. Repe, Zakaj so Slovenci vstopili v Jugoslavijo in zakaj so iz nje odšli?, p. 27; Borut Klabjan, Oblikovanje jugoslovanskih meja. T. G. Masaryk in vprašanje jugoslovansko-italijanske meje po prvi svetovni vojni, in: Jugoslavija v času-devetdeset let od nastanka prvo jugoslovenakse države, ed. Bojan Balkovec, Ljubljana 2009, p. 281; L. Hladký, D. Blažek, Česko-slovinské vztahy, p. 34; Aleksandra Gačić, Dr. Bogumil Vošnjak - politik in diplomat, (doktorska disertacija), Filozofska fakulteta Univerzitet u Mariboru, 2014.

20 Драгош Петровић, Предраг Крејић, Српски и југословенски дипломатски представниции у Сједињеним Америчким Држсавама, “Архив Југославије. Часопис Архива Југославије”, 2007, vol. 8, no. 1-2, p. 193.

21 A. Rahten, Očrt slovenske diplomacije ali diplomacije Slovencev, p. 651; Д. Петровић, П. Крејић, Српски и југословенски дипломатски представници у Сједињеним Америчким Државама, p. 193.

22 Yugoslav Ministry of Foreign Affairs was using supreme mufti in Belgrade Mehmed Zeki for informal mission in Turkey (Archive of Yugoslavia, Records of the Legation of the Kingdom of Yugoslavia in Turkey - Constantinople, Ankara (370), box 6, folder 31, folios 209-214 - further referred as: AY, 370). Prominent tucoroligst Fehim Barjaktarević was hired as official translator for documents in Turkish language (AY, 334-Personal Section-137-450, folios 488 (pages 1-6), 489-491, 510-512). Nedžib Abdurahmanović was sent to Turkey for work toward Albanian emigrants (AY, 370-6-31, folios 190-203, 209-214, 218, 250-253; AJ, 370-22-70, folios 176, 208; AY, 370-23-72, folios 152, 217, 218). 
and abroad posts. Exceptions were the cases of the first Yugoslav foreign minister Ante Trumbić and plenipotentiary ministers Josip Smodlaka and Ante Pijus TresićPavičić. Most of Croats were accepted in Yugoslav service on the grounds of proven adherence to the idea of the South Slav liberation and unification, friendly relations toward Karađorđević dynasty, or states interests since their compatriots represented a large portion of Yugoslav Diaspora in some European and American countries. Such was the case of Ante Tresić-Pavičić who was an advocate of the liberation and unification of the South Slavs. ${ }^{23}$ He was appointed as plenipotentiary minister in Madrid and Lisbon in the first post-war years and later plenipotentiary minister in Washington 1922-1927. His recall to the Kingdom of SCS was caused by conflict with prominent radicals. ${ }^{24}$ Exceptions were appointments of Trumbić and Smodlaka as both cases were the result of the internal political situation in the Kingdom of SCS. Ante Trumbic became the first foreign minister as a compromise solution of the political representatives of Serbs, Croats and Slovenes in the newly formed state. ${ }^{25}$ Josip Smodlaka was appointed the plenipotentiary minister in Vatican with the sole intention of the Serbian elite to exclude him from political life in the Kingdom of SCS. ${ }^{26}$ Members of national minorities comprised the least part of diplomatic and consular staff.

Although the Serbs were holding firmly in their hands the Ministry and diplomatic-consular service, it did not mean that the staff were a compact body. Power struggles between the Crown, the PRP, the YDP and the White Hand had their impact on officials and clerks of the Ministry of Foreign Affairs. One of the major factors in the careers of the staff was their ties with opposed groups in the Serbian elite. Even the former Serbian diplomats, who proved themselves during the creation of the new Foreign Policy since 1903, were not immune to the new tendency in the Yugoslav service. One of the first deputy foreign ministers Milan Đ. Milojević admitted in his memoirs that struggles between the PRP and the YDP had a devastating influence on clerks as they started mutual imputations immediately after the First World War.

${ }^{23}$ С. Мићић, Од бирократије до дипломатије, р. 184; Предраг Крејић, Конзуларна представништва Краљевине Југославије у Сједињеним Америчким Државама (Њујорк и Чикаго). Установа и грађа, “Архив Југославије. Часопис Архива Југославије”, 2013, vol. 14, no 1-2, p. $22-24$.

${ }^{24}$ Fedora Ferluga-Petronio, Ante Tresić Pavičić i Prvi svjetski rat, "Dani hrvatskog kazališta: Građa i rasprave o hrvatskoj književnosti i kazalištu”, vol. 41, no 1 (2015), p. 137-146; П. Крејић, Конзуларна представништва Краљевине Југославије у Сједињеним Америчким Државама (Њујорк и Чикаго), р. 27; Д. Петровић, П. Крејић, Српски и југословенски дипломатски представници у Сједињеним Америчким Држсавама, p. 191; Ivo Petrinović, Politički lik Ante Tresića Pavičića. Uvodni članak s prilozima iz Tresićevog dnevnika, "Starine, 2005, vol. 63, p. 197-200, 208-210; Ivo Petrinović, Politički život $i$ nazori Ante Tresića-Pavičića, Split 1997.

25 Ivo Petrinović, Ante Trumbić: političko shvaćanja i djelovanje, Zagreb 1986.

26 Josip Smodlaka was opposing centralist regime introduced in the Kingdom of SCS through Constitution from 1921. King Aleksandar and Nikola Pašić agreed on his admission in the Foreign Service on the pretext that his political agitation would be halted. Foreign Minister Momčilo Ninčić did not have confidence in his diplomatic activities since Josip Smodlaka was not a Serb (Коста Милутиновић, Јосип Смодлака као дипломат, “Зборник Матице српске за историју”, 1986, no 34, p. 100, 101, 105). 
According to the preserved archive material he was the only official who warned minister from opposing Serbian party, Milojević was a democrat while Ninčić was a radical, about the destructive results of this enduring practice on the entire staff. One of the last deputy foreign ministers Ivo Andrić confirmed the statements of his colleague that manyretirements or even dismissals from the service were motivated by party interests. ${ }^{27}$

The power struggle among the elite circles was not the only reason for the new managing of the Foreign Service. The Kingdom of Serbia had two great powers as neighbors, the Habsburg Monarchy and the Ottoman Empire, and Serbian statesmen were using all of available capacities in conducting Foreign Policy of one small state. Therefore, diplomatic and consular staff was primarily recruited for their skills and not for their political affiliations. On the other hand, the Kingdom of SCS / Yugoslavia was one of the strongest states in the Balkans and in the Danubian region after the First World War and had only Italy as the neighboring great power and constant dangerous threat. Greater political and military strength as well as stronger international position reduced the vulnerability of the Yugoslav state to external menaces. Statesmen and politicians were using the new situation for mutual struggle over power and consequently cleared the path for the influence of political parties over states institutions. On the other hand, stronger international positions of Yugoslav state reduced importance of professional abilities of the diplomatic and consular officials and clerks. Hence, the internal power struggle among elite circles became one of the major factors in the careers of the Foreign Service staff due to their links with opposed high-ranking groups.

The influence of radicals and democrats on career development of diplomatic and consular clerks was most prominent during 1920s. Each time one of those two parties was running the Ministry of Foreign Affairs, their supporters were shifted in the first echelon of the service, receiving desirable posts abroad and secured fast advancement in bureaucratic hierarchy. Likewise, their opponents were assigned to unappealing duties. Usually they were recalled to Belgrade or appointed to less important posts in foreign countries, and those unlucky ones were retired or dismissed from the service. Senior officials who occupied high-ranking positions in their long careers were able to confront those kinds of treatment either by direct confrontation with the minister or by resignation on the service. As was the case with pre-war clerks and officials, same treatment was more evident among the generations which entered service after 1918. Diplomatic and consular career was enticing for the young members of prominent families because it had alluring prospect of the imagined high-life in international privileged circles. As social influence was divided among families whose members were high-ranking politicians and army officers, younger members of those families had greater chances to enter the service of the Ministry of Foreign Affairs. The ad-

27 С. Мићић, Од бирократије до дипломатије, p. 169-176; др Милан Ђ. Милојевић, Балканска равнотежа. Сећања краљевог дипломате, Београд 1994, p. 184, 185. 
mitted candidates from lesser social background sought to provide themselves with a better career by getting married with girls from prominent families. Regardless of their origin,the careers of younger generations of diplomatic and consular clerks were greatly influenced by party struggles. Consequently, they were swiftly becoming the supporters of radicals or democrats. Some of them presented themselves as the followers of both parties, since they were pledging formal allegiance to current administration. Each time the ministers were dismissed the lists of ineligible clerks were compiled based on their party affiliations. As a measure of protection, younger generations of radicals and democrats introduced a new practice. They created groups of mutual support, so the members of the party in power protected those who were at that time in opposition. ${ }^{28}$

Nepotism, political protectionism and corruption became evident in the Yugoslav civil service corollary of undefined situation in the central state institutions. According to the British plenipotentiary ministers in Belgrade it was the result of a mixture of Ottoman heritage and Balkan mentality. British diplomats explained on the same ground the regular interference of politicians in bureaucratic affairs. ${ }^{29}$ As one of the French plenipotentiary ministers in Belgrade observed, clientelism in the ranks of the Serbian elite became a major factor in the Yugoslav Diplomatic and Consular Service. The career development of clerks was determined by family connections and party affiliations. ${ }^{30}$ State administration became an important element in the King's dictatorship after January 6, 1929. The newly formed government of Petar Živković proclaimed the establishment of efficient bureaucracy as one of the first and most important tasks. Yet, certain changes which were introduced did not provide anticipated results. ${ }^{31}$ Those inadequacies were clearly evident in the Yugoslav Foreign Service as well. To former Serbian diplomats who held high posts in Yugoslav service it was evident since mid-1920s that there was a huge difference between pre-War and post-War clerks. The former were characterized by their devotion to state service, conscientious work and protection of the state interests at all costs; while the latter were considered opportunists to whom career progress was far more important than anything else and their personal successes were based on family ties and party affiliation. ${ }^{32}$

Intimate relations with military circles were an important factor for progress in career as well as for the protection from the impact of struggle among political parties. The influence of the generals closely related to King Aleksandar is exemplary. Among them, the Chief of the General Staff general Petar Pešić and the Prime Minister Petar Živković had a prominent role as non-institutional factors in the Yugoslav Ministry of

\footnotetext{
${ }^{28}$ For further reading: С. Мићић, Од бирократије до дипломатије.

29 Љ. Димић, Историја српске државности, III, p. 101.

${ }^{30}$ Dr Stanislav Sretenović, Francuska i Kraljevina Srba, Hrvata i Slovenaca 1918-1929, Beograd 2008, p. 238.

${ }^{31}$ B. Petranović, Istorija Jugoslavije 1918-1988, I, p. 190, 196; Mr Ivana Dobrivojević, Državna represija u doba diktature kralja Aleksandra 1929-1935, Beograd 2006, p. 49, 54, 57, 58.

32 С. Мићић, Од бирократије до дипломатије, p. 169-186; 217-221; 321-356.
} 
Foreign Affairs and diplomatic-consular service. We have already explained the aspirations of the latter, and as of the former he was so sure of himself that he had at least once used inappropriate language in communication with the Deputy Minister for Foreign Affairs Jovan T. Marković in order to secure privileges for one of his protégés among diplomatic clerks. The case of Svetozar Rašić, the son of the first Yugoslav Army and Navy Minister, clearly indicates that he was protected as a democrat from malicious actions of the radicals since he had a foothold in the highest military circles. $^{33}$

When King Aleksandar assumed dictatorial power in January 1929, he had already a leading role in Yugoslav Foreign and Internal Policy. His power grew even stronger since all political parties were disbanded and his close collaborator and the leader of the White Hand Petar Živković was appointed a Prime Ministers. Laws introduced for central state institutions afforded full control of King Aleksandar over government. All ministers were subjected directly to the monarch who appointed or dismissed them as he pleased. Some groups of former radicals and democrats accepted the new state policy and entered into service under dictatorship. After assuming total political power, King Aleksandar extended his influence on the personal questioning of clerks. As far as the Ministry of Foreign Affairs was concerned, he started appointing persons close to him to the highest positions, mainly as plenipotentiary ministers, even though they had no experience in diplomatic field of work. Such were the cases with retired army general Petar Pešić, Budisav Grgur Anđelinović, Albert Kramer and Jovan Đonović. The new practice of the Crown's authority was poorly received by the officials of the Ministry of Foreign Affairs, while it meant disposition or even retirement of professional diplomats. ${ }^{34}$ Yet, former democrat and active minister Vojislav Marinković did not have strength, courage nor institutional support to oppose King's will. Marinković was preserving his position in governments through personal loyalty to the King Aleksandar and thought of him as a counterweight to the influence of the White Hand and ministers from the dissolved PRP, which was supporting Petar Živković during the 1920s. ${ }^{35} \mathrm{He}$ was using good relations with the Crown in order to oppose Živković's attempts to interfere in the Foreign Policy and diplomatic activi-

${ }^{33} \mathrm{Ibid}$, p. 211, 214.

${ }^{34}$ Ibid, p. 135, 136.

${ }^{35}$ According to the diary of his personal secretary Kosta St. Pavlović, Vojislav Marinković was conferring directly with King Aleksandar on important question of internal state policy. On the other hand, he had differences in views with ministers Nikola Uzunović, Milan Srškić and Božidar Maksimović (Historical Archive of Belgrade, Legate of Kosta Stevana Pavlovića - London, box no. 15 Diary for 1930 31 , diary entrances for $6^{\text {th }}, 11^{\text {th }}, 12^{\text {th }}$ and $18^{\text {th }}$ October $1930,26^{\text {th }} \mathrm{July}, 3^{\text {rd }}, 13^{\text {th }}, 21^{\text {st }}, 27^{\text {th }}$ and $31^{\text {st }}$ August, $2^{\text {nd }}, 3^{\text {rd }}, 17^{\text {th }}$ and $19^{\text {th }}$ September, $26^{\text {th }}$ October, $7^{\text {th }}$ November 1931). Two and a half decades later, Kosta Pavlović presented a different interpretation in the five volumes of the book on Vojislav Marinković as he claimed that Minister of Foreign Affairs had complete autonomy in his work from King's wishes and intentions (Kosta St. Pavlović, Vojislav Marinković i njegovo doba (1876-1935), knjiga druga, treća, četvrta i peta, London 1956, 1957, 1960). 
ties. The Prime Minister was usurping lawful rights of the Minister of Foreign Affairs and meddling in official communication with the Diplomatic Corps in Belgrade. ${ }^{36}$

The new redistribution of political power formally interrupted the previous influence of the PRP and the YDP on the careers of the diplomatic and consular staff. In fact, the affiliation to political groups continued to be an important factor. Seldom replacement of ministers of foreign affairs was providing more stable careers for the clerks. Nevertheless, it did not mean that there were no unmerited promotions nor unjustified inconsiderations, retirements or dismissals from the service. Miroslav Spalajković, the closest friend of King Aleksandar among Yugoslav diplomats, tried soon after dictatorship was announced to undermine the positions of Vojislav Marinković as the Minister of Foreign Affairs. denounced him to the King, accusing him of turning the Ministry of Foreign Affairs into a group of his supporters. ${ }^{37}$ Well known and fairly documented case of the conflict between the Minister of Foreign Affairs Bogoljub Jevtić, who was close with the King Aleksandar, and the Plenipotentiary Minister in Rome Milan Rakić, who was not only famous poet but also close friend with Vojislav Marinkovic then the former PM and Minister of Foreign Affairs, was clearly depicting struggles between different groups among the Serbian elite. ${ }^{38}$

After the assassination of the King Aleksandar in Marseille, in October 1934, there were visible changes in central state institutions and in the Yugoslav Foreign Service. Among the three members of the Regency the Prince Pavle Karađorđević was the most prominent figure. ${ }^{39}$ At the end of 1934 and at the beginning of 1935, he changed the Protocol in order to communicate independently off two other members of the Regency with new members of the Diplomatic Corps in Belgrade. ${ }^{40}$ Bogoljub Jevtić preserved his place as the Minister of Foreign Affairs, at first, due to close relations with the late king and the support of general Petar Živković. He had received a mandate for the new government only to be replaced after parliamentary elections in 1935. ${ }^{41}$ New Prime Minister and Minister of Foreign Affairs was Milan Stojadinović.

36 С. Мићић, Од бирократије до дипломатије, p. 138, 139.

37 According to Miroslav Spalajković, Vojislav Marinković did not only favor democrats among clerks, yet managed to gain supporters among some of prominent members of the dissolved PRP (Зоран Д. Бајин, Мирослав Спалајковић (1861-1957). Биографија, (докторска дисертација) Филозофски факултет Универзитета у Београду, 2016, p. 462).

${ }^{38}$ For further reading: Радован Поповић, Жудња за фраком. Српски писци у дипломатији, Лесковац-Београд 2011, p. 40-44; Коста Ст. Павловић, Онакви какве сам их знао, Београд 2004, p. 206-208; Андреј Митровић, „Дипломата Милан Ракић и његово сведочење о историји“, Милан Ракић. Конзулска писма 1905-1911, (прир. Андреј Митровић), Београд 1985, р. 18, 19; Војислав Ј. Вучковић, Пензионисање Милана Ракића, “Зборник историје књижевности, Одељење литературе и језика САНУ”, 1961, vol. 2.

39 Jacob B. Hoptner, Jugoslavija u krizi 1934-1941, Rijeka 1972, p. 70, 71.

40 С. Мићић, Од бирократије до дипломатије, p. 66.

${ }^{41}$ Мр Драган Тешић, Југословенска радикална заједница у Србији 1935-1939., Београд 1997, p. 18-21; Todor Stojkov, Vlada Milana Stojadinovića 1935-1937, Beograd 1985, p. 13-17; J. B. Hopter, Jugoslavija u krizi 1934-1941, p. 75. 
He established close contacts with the Prince Pavle and got support from general Živković to overthrow Jevtić. ${ }^{42}$ Old structures in Serbian elite were gradually losing their ground. After unsuccessful attempt on the life of a PM, in March 1936, general Petar Živković was released from his post of the Minister of the Army and Navy. Stojadinović was replaced in February 1939. The new PM Dragiša Cvetković was not a man with a strong political background, and he was merely a state official who owed his position to the Prince Pavle. ${ }^{43}$

Changes that occurred after the assassination of King Aleksandar and shifts of power among Serbian elite left a mark in the Yugoslav Foreign Service, during 19351939. Miroslav Spalajković, Živojin Balugdžić and Boško Čolak-Antić, plenipotentiary ministers in Paris, Berlin and Bucharest respectively, who had undisputable positions due to close personal ties with the late kings Petar and Aleksandar ${ }^{44}$ were withdrawn from their posts during the summer of 1935. Spalajković and Balugdžić were immediately retired, ${ }^{45}$ while Čolak-Antić got a prominent place at the Court at first only to be retired next year. ${ }^{46}$ Soon after, the protégés and close associates of the three distinguished diplomats were replaced from their attractive posts and given less significant positions in Yugoslav diplomatic-consular service. The worst case scenario was applied on Spalajković's coworkers as he was probably the only personal

\footnotetext{
42 Д. Тешић, Југословенска радикална заједнииа у Србији 1935-1939., p. 23-31; T. Stojkov, Vlada Milana Stojadinovića 1935-1937, p. 17-23, 34; J. B. Hoptner, Jugoslavija u krizi 1934-1941, p. 75, 76.

${ }^{43}$ For further reading: Д. Тешић, Југословенска радикална заједница у Србији 1935-1939.; B. Petranović, Istorija Jugoslavije 1918-1988, T. Stojkov, Vlada Milana Stojadinovića 1935-1937; I; J. B. Hoptner, Jugoslavija u krizi 1934-1941.

${ }^{44}$ Arnold Suppan, Jugoslawien und Österreich 1918-1938. Bilaterale Außenpolitik im europäischen Umfeld, Wien-München 1996, S. 336; S. Sretenović, Francuska i KraljevinaSrba, Hrvata i Slovenaca 1918-1929,p. 295; Драгољуб Р. Живојиновић, Краљь Петар I Карађорђевић у изгнанству 1844-1903. године, (Београд 2009), ${ }^{2}$ р. 428, 435-439, 445, 447; Д. Р. Живојиновић, Краљь Петар I Карађорђевић у отацбини 1903-1914. године, р. 53, 54,69, 74, 77, 116, 134, 181, 182, 184, 189-193, 260; Бранислав Глигоријевић, Краљ Александар Карађорђевић у европској политици, Београд 2010, p. 6, 7;3. Д. Бајин, Мирослав Спалајковић (1861-1957), p. 355-384; С. Мићић, Од бирократије до дипломатије, р. 178.

${ }^{45}$ The first rumors on Spalajković's replacement from Paris were circulating immediately after the assassination of King Aleksandar, in October 1934. The retirement of Yugoslav plenipotentiary minister in Paris initiated Minister of Foreign Affairs Milan Stojadinović only two weeks after the formation of his first government (З. Д. Бајин, Мирослав Спалајковић (1861-1957), p. 493, 498-501). Almost simultaneously, Živojin Balugdžić insisted on his decision to be retired (AY, 334-Personal Section-137-460, folio 346). Decree for Spalajković's retirement was signed on $26^{\text {th }}$ June and for Balugdžić on $15^{\text {th }}$ July 1935 (AY, 334-Personal Section-137-460, folio 344; AY, 334-Personal Section-192-515, folio 442).

${ }^{46}$ Boško Čolak-Antić was at first withdrawn from Bucharest and appointed the Minister of the Court, in March 1935. According to laws which were in force he was considered an expendable diplomat for next year and was retired in March 1936 (AY, 334-Personal Section-203-526, folios 277-282, 310; Archive of the Serbian Academy of Science and Arts, Personal records of Milan Antić (-14.387), documents no. 8503, 8511, 8682).
} 
friend of late King Aleksandar among Yugoslav diplomats. ${ }^{47}$ As such Spalajković had for more than a decade absolute independence from the Ministry of Foreign Affairs ${ }^{48}$ which he (ab)used to create his own coterie in the Legation in Paris. ${ }^{49}$ The diplomatic staff at the legations in Berlin and Bucharest were less exposed to purge as there was only an intention to replace counselors while lower-ranking clerks preserved their positions. ${ }^{50}$ All those replacements indicated it was not a standard rotation within Yugoslav diplomatic service, yet that was a product of changing tides in the Serbian elite after the assassination of the King Aleksandar. On the other hand, Prince Pavle proposed to Milan Rakić to reactivate him as a Yugoslav diplomat and offered him a post of plenipotentiary minister in London. ${ }^{51}$ After Milan Stojadinović was removed from power, Prince Pavle chose Aleksandar Cincar-Marković as a new Minister of Foreign Affairs. That was the only case during the Interwar Period that professional diplomat was appointed as Yugoslav foreign minister. ${ }^{52}$

The role of Slovenians and Croats during the period 1935-1939, was somewhat different. The greater political role which Slovene politicians had in the internal politics in governments of Milan Stojadinović and Dragiša Cvetković as they were helping Serbian politicians to keep Croats in a political wedge, created the possibility of employing a larger number of Slovenians in the Yugoslav diplomatic and consular services. ${ }^{53}$ Thus, the Serbs were gradually losing some of the positions they were holding

${ }^{47}$ For further reading: 3. Д. Бајин, Мирослав Спалајковић (1861-1957), p. 499. British plenipotentiary minister in Belgrade Sir Neville Henderson, who was also regarded as a close friend of Yugoslav monarch, was convinced that King Aleksandar had a very small group of friends due to his character which he was explaining by his personal life experiences during 1903-1929 (Britanci o Kraljevini Jugoslaviji. Godišnji izveštaji Britanskog poslanstva u Beogradu 1921-1938, knjiga druga (1931-1938), (prir. Živko Avramovski), Beograd-Zagreb 1986, p. 86, 87).

48 According to preserved archival sources and memoirs, King Aleksandar offered similar freedom for selection of subordinated personnel only to Jovan Đonović, who he personally selected as plenipotentiary minister in Tirana in December 1931 (С. Мићић, Од бирократије до дипломатије, p. 136). The preserved archival records do not say much on the liberties that other King's diplomats might have. Yet cases of Spalajković and Đonović might implicate that all of those who were favored by King Aleksandar had a similar freedom of action.

${ }^{49}$ Counselor, two secretaries and archivist of the Legation in Paris were assigned to new posts in the course of one month after the retirement of Miroslav Spalajković (AY, 334-Personal Section-165-488, folios 800, 801, 803; AJ, 334-Personal Section-174-497, folios 922, 923, 933).

${ }^{50}$ Counselor of the Legation in Berlin was sent to new post only after new plenipotentiary minister Aleksandar Cincar-Marković arrived to German capital (AY, 334-Personal Section-162-485, folio 596; AY, 334-Personal Section-187-510, folios 791, 793, 794, 795, 797; AY, 334-Personal Section-202-525, folios 518, 522-525). Similar case was in Bucharest. After Nikola (Ninko) Perić succeeded Boško ČolakAntić as plenipotentiary minister in Romania, the counselor of the Legation in Bucharest was assigned to new post and left Bucharest during next months (AY, 334-Personal Section-172-494, folios 153, 154, 156; AY, 334-Personal Section-181-504, folio 1159).

${ }^{51}$ Р. Поповић, Жудња за фраком, р. 44, 45.

52 Bogdan Krizman, Vanjska politika jugoslavenske države 1918-1941. Diplomatsko-historijski pregled, Zagreb 1975, p. 103.

53 A.Rahten, Očrt slovenske diplomacije ali diplomacije Slovencev, p. 657. 
up-until-then. The signing of Cvetković-Maček's agreement in August 1939, which was supposed to be the solution of the Serbo-Croatian disputes, influenced the introduction of an ethnic key for employees in the Ministry of Foreign Affairs. According to the agreement it was intended to employ four Croatian and one Slovenian clerk on each of five Serbian employees. The aim was to redefine the role of the three ethnic groups in the conduct of foreign policy, diplomatic and consular activities. Nevertheless, the Serbian elite was not too keen on easily abandoning thieir existing standings. In order to retain the leading positions in the Ministry of Foreign Affairs and diplomatic-consular services, the tendency was to appoint newly hired Croatian and Slovenian clerks on insignificant positions or duties unattractive for most of the staff. $^{54}$

\section{CONCLUSION}

The struggles for power in the ranks of the Serbian elite became a very important factor in the selection of new employees, progress and ending of the career of the staff in the Ministry of Foreign Affairs. Only the first and the last minister of foreign affairs were not members either of the PRP or the YDP. The appointments of Ante Trumbic and Aleksandar Cincar-Marković were determined by the political consensus and the international position of the Yugoslav Kingdom. Former Serbian diplomats who entered in the new Yugoslav service swiftly adjusted to the newly emerging situation, but did not neglect the state interests even when they were dissatisfied with their position. If deeply unsatisfied they were prepared to resign from their posts rather than to neglect their duties. Clientelism which emerged in the ranks of the Serbian elite had a different impact on the new generations of the Yugoslav diplomats who were admitted after 1918. They had a greater interest in the career advancement than in protecting state interests. Thus, the conflicts of the Serbian elites, which were evident from 1913, were transferred to the new Yugoslav bureaucratic structure. This process had a negative impact on the Ministry of Foreign Affairs and the diplomatic-consular service. Since mid-1920s it was evident there was a great difference between pre-War and post-War clerks who had diverse priorities in their lines of work. Those processes had a long-term negative impact on the work of the Yugoslav Ministry of Foreign Affairs and Diplomatic-consular service. On the other hand, the employment and career development of Slovenes and Croats were determined primarily through agreements of political parties which were the bases for the formation of governments.

${ }^{54}$ С. Мићић, Од бирократије до дипломатије, p. 184; A. Rahten, Očrt slovenske diplomacije ali diplomacije Slovencev, p. 659. 


\section{BIBLIOGRAPHY}

Bajin Zoran D., Miroslav Spalajković (1861-1957). Bibliografija (doktorska disertacija), Filozofski fakultet u Beogradu, 2016 [Бајин Зоран Д., Мирослав Спалајковић (1861-1957). Биографија].

Bataković Dušan, Sukob vojnih i civilnih vlasti u Srbiji u proleće 1914. „Istorijski časopis”, 1982-1983, vol. 29-30.

Bataković Dušan, Nikola Pašic, les radicaux de et la "Main noire": Les défis à la démocratie parlementaire serbe (1903-1917). „Balcanica”, 2006, vol. 37.

Bataković Dušan, Storm over Serbia: the Rivalry between Civilian and Military Authorities (1911-1914), "Balcanica", 2013, vol. 46.

Bjelajac Mile S., Generali i admirali Kraljevine Jugoslavije 1918-1941. Studija o vojnoj eliti i biografski leksikon, Beograd 2004.

Bjelajac Mile, Vojska kao fatkor modernizacije, in: Srbija u modernizacijskim procesima XX veka: naučni skup, ed. Latinka Perović, Marija Obradović, Dubravka Stojanović, Beograd 1994.

Bjelajac Mile, Vojska Kraljevine Srba, Hrvata i Slovenaca 1918-1921, Beograd 1988.

Bjelajac Mile, Vojska Kraljevine SHS/Jugoslavije 1922-1935, Beograd 1994.

Dimić Ljubodrag, Istorija srpske državnosti, vol. 3: Srbija u Jugoslaviji, Novi Sad 2001 [Димић Љубодраг, Историја српске државности, књ. 3: Србија у Југославији].

Dobrivojević mr Ivana, Državna represija u doba diktature kralja Aleksandra 1929-1935, Beograd 2006.

Djordjević Dimitrije, The Role of the military in the Balkans in the nineteenth century, in: Der Berliner Kongress von 1878: Die Politik der Grossmächte und die Probleme der Modernisierung in Südosteuropa in der zweiten Hälfte des 19. Jahrhunderts, eds. Ralph Melville, Hans-Jürgen Schröder, Wiesbaden 1982.

Ferluga-Petronio Fedora, Ante Tresić Pavičić i Prvi svjetski rat, „Dani hrvatskog kazališta: Građa i rasprave o hrvatskoj književnosti i kazalištu”, 2015, vol. 41, no 1.

Gačić Aleksandra, Dr. Bogumil Vošnjak - politik in diplomat (doktorska disertacija), Filozofska fakulteta, Univerzitet u Mariboru 2014.

Gligorijević Branislav, Parlament i političke stranke u Jugoslaviji (1919-1929), Beograd 1979.

Gligorijević Branislav, Kralj Aleksandar Karađorđević: srpsko-hrvatskispor, Beograd 2002 [Глигоријевић Бранислав, Краљ Александар Карађорђевић: српско-хрватски спор].

Gligorijević Branislav, Kralj Aleksandar Karađorđević u evropskoj politici, Beograd 2010 [Глигоријевић Бранислав, Краљ Александар Карађорђевић у европској политици].

Gligorijević Branislav, Istorija Demokratske stranke 1919-1928, Beograd, 2010 [Глигоријевић Бранислав, Историја Демократске странке 1919-1928, Београд, 2010].

Hladký Ladislav, Blažek David, Česko-slovinské vztahy, in: Vztahy Čechi̊ s národy a zeměmi jihovýchodni Evropy, ed. Ladislav Hladký and others, Praha 2010.

Hoptner Jacob B., Jugoslavija u krizi 1934-1941, Rijeka 1972.

Jovanović Nadežda, Politički sukobi u Jugoslaviji 1925-1928, Beograd 1974 [Јовановић Надежда, Политички сукоби у Југославији 1925-1928].

Kazimirović Vasa, Crna ruka: ličnosti i događaji u Srbiji od Majskog prevrata 1903. do Solunskog procesa 1917. godine, Novi Sad 2013.

Keršić-Svetel Marteja, Česko-slovenski stiki med svetovnima vojnama (1. del), „Zgodovinski časopis”, 1995, vol. 49, no 2.

Keršić-Svetel Marteja, Česko-slovenski stiki med svetovnima vojnama (3. del), „Zgodovinski časopis”, 1995, vol. 49, no 4.

Klabjan Borut, Oblikovanje jugoslovanskih meja. T. G. Masaryk in vprašanje jugoslovansko-italijanske meje po prvi svetovni vojni, in: Jugoslavija v času-devetdeset let od nastanka prvo jugoslovenakse države, ed. Bojan Balkovec, Ljubljana 2009.

Krejić Predrag, Konzularna predstavništva Kraljevine Jugoslavije u Sjedinjenim Američkim Državama (Njujork i Čikago). Ustanova i građa, „Arhiv Jugoslavije. Časopis Arhiva Jugoslavije”, 2013, vol. 14, 
nо 1-2 [Крејић Предраг, Конзуларна представништва Краљевине Југославије у Сједињеним Америчким Државама (Њујорк и Чикаго). Установа и грађа, “Архив Југославије. Часопис Архива Југославије", 2013].

Krizman Bogdan, Vanjska politika jugoslavenske države 1918-1941. Diplomatsko-historijski pregled, Zagreb 1975.

MacKenzie David, Apis, the Congenial Conspirator: the Life of Colonel Dragutin T. Dimitrijević, New York 1989.

Mićić Srđan, Mission of Konstantin Todorov in North America 1927-1928: Yugoslav Foreign Service vs. Macedonian-Bulgarian organizations in North America, „Tokovi istorije” [„Токови историје”], 2015, no 1.

Mićić Srđan, Od birokratije do diplomatije, Istorija jugoslovenske diplomatske službe 1918-1939, Beograd 2018 [Мићић Срђан, Од бирократије до дипломатије. Историја југословенске дипломатске службе 1918-1939].

Milojević dr Milan Đ., Balkanska ravnoteža. Sećanja kraljevog diplomate, Beograd 1994 [Милојевић др Милан Ђ., Балканска равнотежа. Сећања краљевог дипломате].

Milutinović Kosta, Josip Smodlaka kao diplomat, „Zbornik Matice srpske za istoriju”, 1986, no 34 [Милутиновић Коста, Јосип Смодлака као дипломат, „Зборник Матице српске за историју”, $1986]$.

Mišić Saša, Albanija: prijatelj i protivnik. Jugoslovenska politika prema Albaniji 1924-1927, Beograd 2009 [Мишић Саша, Албанија: пријатељ и противник. Југословенска политика према Албанији 1924-1927].

Mitrović Andrej, Diplomata Milan Rakić i njegovo svedočanje o istoriji, in: Milan Rakić. Konzulska pisma 1905-1911, ed. Andrej Mitrović, Beograd 1985 [Митровић Андреј, Дипломата Милан Ракић и његово сведочење о историји, у: Милан Ракић. Конзулска писма 1905-1911, прир. Андреј Митровић].

Newman John Paul, Yugoslavia in the shadow of war: veterans and the limits of state building, 19031945, Cambridge 2015.

Ostojić-Fejić dr Ubavka, Sjedinjene Američke Države i Srbija 1914-1918, Beograd 1994.

Pavlović Kosta St., Vojislav Marinković i njegovo doba (1876-1935), vol. 2-5, London 1956, 1957, 1960.

Pavlović Kosta St., Onakvi kakve sam ih znao, Beograd 2004 [Павловић Коста Ст., Онакви какве сам uх знао].

Petranović Branko, Istorija Jugoslavije 1918-1988, vol. 1 (Kraljevina Jugoslavija 1914-1941), Beograd 1989.

Petrinović Ivo, Politički lik Ante Tresića Pavičića. Uvodni članak s prilozima iz Tresićevog dnevnika, "Starine", 2005, vol. 63.

Petrinović Ivo, Politički život i nazori Ante Tresića-Pavičića, Split 1997.

Petrinović Ivo, Ante Trumbić: političko shvaćanja i djelovanje, Zagreb 1986.

Petrović Dragoš, Krejić Predrag, Srpski i jugoslovenski diplomatski predstavnici u Sjedinjenim Američkim Državama, „Arhiv Jugoslavije. Časopis Arhiva Jugoslavije”, 2007, vol. 8, no 1-2 [Петровић Драгош, Крејић Предраг, Српски и југословенски дипломатски представници у Сједињеним Америчким Државама, “Архив Југославије. Часопис Архива Југославије”, 2007].

Petrović mr Ljubomir, Jugoslovenska država i društvo u periodici 1920-1941, Beograd 2000 [Петровић мр Љубомир, Југословенска држава и друштво у периодици 1920-1941].

Petrović Milić F., Pljevaljci u službi diplomatije Kraljevine Jugoslavije (1919-1945), „Glasnik Zavičajnog muzeja”, 2013, vol. 8-9 [Петровић Милић Ф., Пљеваљцуи у служби дипломатије Краљевине Југославије (1919-1945), „Гласник Завичајног музеја”, 2013].

Popović Radovan, Žudnja za frakom. Srpski pisci i diplomati, Leskovac-Beograd 2011 [Поповић Радован, Жудња за фраком. Српски писци у дипломатији].

Radojević Mira, Milan Grol, Beograd 2014 [Радојевић Мира, Милан Грол, Београд, 2014]. 
Rahten Andrej, Očrt slovenske diplomacije ali diplomacije Slovencev, „Teorija in praksa”, 2011, vol. 43, no 3 .

Repe Božo, Zakaj so Slovenci vstopili v Jugoslavijo in zakaj so iz nje odšli?, in: Jugoslavija v času - devetdeset let od nastanka prvo jugoslovense države, ed. Bojan Balkovec, Ljubljana 2009.

Rastoder Šerbo, Crnogorska emigracija u vrijeme nestanka Crne Gore i nastanka Sovjetske Rusije”, „Matica”, 2016, no 65.

Sretenović dr Stanislav, Francuska i Kraljevina Srba, Hrvata i Slovenaca 1918-1929, Beograd 2008.

Stojkov Todor, Vlada Milana Stojadinovića 1935-1937, Beograd 1985.

Suppan Arnold, Jugoslawien und Österreich 1918-1938. Bilaterale Außenpolitik im europäischen Umfeld, Wien-München 1996.

Tešić mr Dragan, Jugoslovesnka radikalna zajednica u Srbiji 1935-1939, Beograd 1997 [Тешић мр Драган, Југословенска радикална заједница у Србији 1935-1939].

Vučković Vojislav J., Penzionisanje Milana Rakića, „Zbornik istorije knjizevnosti”, 1961, vol. 2 [Вучковић Војислав Ј., Пензионисање Милана Ракића, „Зборник историје књижевности”, 1961].

Živanović Milan, Pukovnik Apis: solunski proceshiljadu devetstosedamnaeste: prilog za proučavanje političke istorije Srbije od 1903. do 1918. godine, Beograd 1955.

Živojinović Dragoljub R., Kralj Petar I Karađorđević u izgnanstvu 1844-1903. godine, Beograd 2009 [Живојиновић Драгољуб Р., Краљ Петар I Карађорђевић у изгнанству 1844-1903. године].

Živojinović Dragoljub R., Kralj Petar I Karađorđević u otadžbini 1903-1914. godine, Beograd 2009 [Живојиновић Драгољуб Р., Краљ Петар I Карађорђевић у отаибини 1903-1914. године]. 
